\title{
Correlations between Eucalyptus Clonal Cutting Quality and Performance after Planting
}

\author{
Fábio Afonso Mazzei Moura de Assis Figueiredo ${ }^{1}$ (D), \\ José Geraldo Araújo Carneiro ${ }^{2}$, Ricardo Miguel Penchel ${ }^{3}$, \\ José Tarcísio Lima Thiebaut ${ }^{2}$, Jupiter Israel Muro $\mathrm{Abad}^{4}$ (D), \\ Deborah Guerra Barroso $^{2}$ (1), Tiago Massi Ferraz ${ }^{1}$ \\ ${ }^{1}$ Universidade Estadual do Maranhão (UEMA), São Luís, MA, Brasil \\ ${ }^{2}$ Universidade Estadual do Norte Fluminense Darcy Ribeiro (UENF), Campos dos Goytacazes, RJ, Brasil \\ ${ }^{3}$ Fibria Celulose S.A., Jacareí, SP, Brasil \\ ${ }^{4}$ Toba Pulp Lestari (TPL), Porsea, Sumatra Utara, Indonesia
}

\begin{abstract}
This study assessed correlations of different characteristics of cuttings in the nursery of three hybrid clones of Eucalyptus grandis $\times$ Eucalyptus urophylla and growth in height after planting. The characteristic that presented greatest correlation with the initial growth was the canopy height and cutting height ratio. At 12 and 24 months in the field, the stem diameter was more important. The parameters assessed in the nursery that correlated positively with growth in the field at three and six months after planting were height, number of leaf pairs, number of root deformations and clod length. At 12 and 24 months the parameters that correlated negatively were diameter, number of leaf pairs and the number of root deformations. Despite presenting significant correlation, root deformations did not interfere in the initial growth of the plants under high rainfall conditions, but the effects became harmful over time resulting in a reduction in plant growth.
\end{abstract}

Keywords: quality score, silviculture, correlation between nursery and field.

\section{Correlações entre a Qualidade de Mudas Clonais de Eucalipto e o Desempenho após o Plantio}

\section{RESUMO}

Este estudo avaliou as correlações de diferentes características de mudas, no viveiro, de três clones híbridos de Eucalyptus grandis $\times$ Eucalyptus urophylla e o crescimento em altura após o plantio. A característica que apresentou maior correlação com o crescimento inicial foi a relação entre o comprimento da copa e a altura da muda. Aos 12 e 24 meses no campo, o diâmetro do caule foi mais importante. Os parâmetros avaliados no viveiro que se correlacionaram positivamente com o crescimento no campo aos três e seis meses após o plantio foram altura, número de pares de folhas, número de deformações radiculares e comprimento de torrão. Aos 12 e 24 meses os parâmetros que se correlacionaram negativamente foram diâmetro, número de pares de folhas e número de deformações radiculares. Apesar de apresentar correlação significativa, as deformações das raízes não interferiram no crescimento inicial das plantas sob condições de alta pluviosidade, mas os efeitos se tornaram prejudiciais ao longo do tempo, resultando em uma redução no crescimento das plantas.

Palavras-chave: qualidade de mudas, silvicultura, correlação entre viveiro e campo. 


\section{INTRODUCTION AND OBJECTIVES}

The production and use of good quality cuttings for commercial plantations is extremely important to obtain high productivity from Eucalyptus plantations (Assis, 2011, Freitas et al., 2009). According to Carneiro (1995), cutting quality is directly related to increased survival and initial growth of recently established plantations. Initial survival appears to be related to the interaction between plant quality (both morphological and physiological) and the field environment.

Research has endeavored to show the importance of cutting morphological characteristics to estimate the performance after planting (Fonseca, 2002). Morphological characteristics are the most used as attributes of cutting quality in forest nurseries and several studies have shown the importance of these characteristics in the performance of the plants in the field (Barroso et al., 2000; Figueiredo et al., 2011; Fonseca, 2002; Freitas et al., 2009). Cutting classification by nursery staff is of a more practical nature, but there is still no more correct definition in order to meet the demands for survival and development, taking into consideration the adversities found in the field (Gomes \& Paiva, 2006).

Gomes et al. (2002) studied different morphological parameters of Eucalyptus grandis in 60-day old seedlings using clustering by Tocher. According to the authors, the height presented relative contribution of $50.26 \%$ and the $\mathrm{H} / \mathrm{D}$ ratio $32.93 \%$ thus together presented a relative contribution of $83.19 \%$ to the cutting quality. However, at 90 days, the most relevant parameter for cutting quality was height, expressing a contribution of $31.42 \%$.

Figueiredo et al. (2014) assessed the effect of root deformations and verified that Eucalyptus cuttings submitted to root deformations presented lower hydraulic conductivity in the root system and consequently fall in gas exchanges and reduction in photosynthetic system II maximum quantic yield.

Freitas et al. (2009) observed no difference in growth in height, diameter, canopy and root biomass in two Eucalyptus grandis $\times$ Eucalyptus urophylla clones until 14 months after planting, in function of the deformations and pruning in the cutting root systems. Correia et al. (2013) studied Eucalyptus grandis $\times$ Eucalyptus urophylla and verified that the cutting age and recipient volume did not influence survival.

The objective of the present study was to verify the correlation of different characteristics of Eucalyptus clonal cuttings in the outplanting phase with growth in height after planting in the field.

\section{MATERIALS AND METHODS}

The experiment was carried out from July 2008 to July 2010 in an area from the company Fibria Celulose S.A., Aracruz, ES, Brazil, a municipality located at $40^{\circ} 11^{\prime} 29^{\prime \prime} \mathrm{W}$ and $19^{\circ} 47^{\prime} 54^{\prime \prime} \mathrm{S}$, the soil is of the experimental area and is classified as dystrophic yellow argisol medium texture, clayey. The experiment consisted in two stages: cutting production for quality assessment; and planting, to assess field performance.

The cuttings were derived from three hybrid clones of Eucalyptus grandis $\times$ Eucalyptus urophylla, produced from the tip of mini rootstocks, ranging in length from 8 to $10 \mathrm{~cm}$ and approximately $2 \mathrm{~mm}$ diameter. The substrate used was a mixture consisting (v:v) of coconut fiber (Amafibra) (30\%), burnt and sieved rice husk (35\%), medium vermiculite (35\%), and fertilized with $2.0 \mathrm{~kg} \cdot \mathrm{m}^{-3}$ osmocote $^{\circ}(19-06-10)$ and $2.0 \mathrm{~kg} \cdot \mathrm{m}^{-3}$ simple superphosphate.

In the field, the cuttings were planted in single plots of 392 plants per clone, totalizing 1,176 plants in $3 \times 3 \mathrm{~m}$ spacing, with basic fertilization of 100 grams 06-30-06 NPK formulation at planting per plant. At planting, a $500 \mathrm{ml}$ dose per plots of pre-hydrated gel stockosorb micro was used. Ninety days after planting, 150 grams $12-00-20 \mathrm{NPK}+0.7 \%$ of B was applied in the projection of the canopy of the plants.

The cuttings were assessed individually at outplanting age at around 100 days. The following parameters were assessed: height $(\mathrm{H})$, stem diameter $(\mathrm{D})$, stem height/ diameter ratio (R-H/D), number of root deformations in the clod periphery (NRD) (strangling, spiraling and bending), number of leaf pairs (NLP), phytosanitary condition (PC) (evaluated by the presence or absence of diseases or leaf spots), chlorophyll index (CI) (evaluated by SPAD), clod length (CL), clod angle (CA) and the canopy/height ratio $(\mathrm{R}-\mathrm{C} / \mathrm{H})$, according to methodology proposed by Penchel (2007) (Table 1). Figure 1 shows the assessment methodologies for the canopy/height ratio, clod length and clod angle characteristics. 
Table 1. Description of morphological and physiological characteristics and phytosanitary conditions of rooted cuttings evaluated in the nursery immediately before planting in the field.

\begin{tabular}{|c|c|c|c|}
\hline Parameter & Evaluation & Unit & Description \\
\hline Height $(\mathrm{H})$ & Quantitative & $\mathrm{cm}$ & $\begin{array}{c}\text { Measuring the height of cuttings with millimetric } \\
\text { ruler. }\end{array}$ \\
\hline Stem diameter $(\mathrm{D})$ & Quantitative & $\mathrm{mm}$ & $\begin{array}{c}\text { Measuring stem diameter of cuttings with } \\
\text { Caliper. }\end{array}$ \\
\hline Number of leaf pairs (NLP) & Quantitative & number & Count the number of leaf pairs. \\
\hline Number of root deformations (NRD) & Quantitative & number & $\begin{array}{l}\text { Count the number of root deformations in the } \\
\text { clod periphery. }\end{array}$ \\
\hline Stem height/Diameter ratio (R-H/D) & Quantitative & number & Relationship between height and stem diameter. \\
\hline Canopy/Height ratio $(\mathrm{R}-\mathrm{C} / \mathrm{H})$ & Quantitative & number & $\begin{array}{l}\text { Relationship between length of the canopy and } \\
\text { height of the cuttings. }\end{array}$ \\
\hline Chlorophyll index (CI) & Quantitative & number & $\begin{array}{l}\text { Measurement with the portable chlorophyll meter } \\
\text { of Opti-Science model - CCM } 200 .\end{array}$ \\
\hline Phytosanitary condition (PC) & Qualitative & grade & $\begin{array}{c}\text { Grade } 1 \text { - cuttings showing symptoms of diseases, } \\
\text { Calonectria spp, leaf spots and vascular diseases; } \\
\text { Grade } 3 \text { - presence of leaf spots; } \\
\text { Grade } 5 \text { - healthy cuttings. }\end{array}$ \\
\hline Clod length (CL) & Qualitative & grade & $\begin{array}{l}\text { Grade } 1-<10 \mathrm{~cm} ; \\
\text { Grade } 2-10 \mathrm{~cm} \text { to } 10,9 \mathrm{~cm} ; \\
\text { Grade } 3-11 \mathrm{~cm} \text { to } 11,9 \mathrm{~cm} ; \\
\text { Grade } 4-12 \mathrm{~cm} \text { to } 12,9 \mathrm{~cm} \\
\quad \text { Grade } 5-13 \mathrm{~cm} .\end{array}$ \\
\hline Clod angle (CA) & Qualitative & grade & $\begin{array}{l}\text { Grade } 1->10^{\circ} \text { degrees; } \\
\text { Grade } 2-8 \text { to } 10^{\circ} \text { degrees; } \\
\text { Grade } 3-4 \text { to } 7^{\circ} \text { degrees; } \\
\text { Grade } 4-1 \text { to } 2^{\circ} \text { degrees; } \\
\text { Grade } 5-0^{\circ} \text { degrees. }\end{array}$ \\
\hline
\end{tabular}

\begin{tabular}{|c|cc|}
\hline Canopy/height ratio & (a) & (b) \\
\hline Clod length & & \\
\hline Clod angle & (c) & \\
\hline
\end{tabular}

Figure 1. Methodology for evaluating the characteristics canopy height/shoot height (a), clod length (b) and clod angle (c). 
Table 2 shows the means and standard deviation of parameters evaluated of rooted cuttings in the nursery immediately before planting in the field.

In the field, the cuttings were assessed for growth in height at three months, six months, one year and two years after planting. Figure 2 shows the climatological data of the experimental area during the 24 months of assessment after planting. The identification of the cuttings in the nursery was maintained in the field for measurement.

The data were analyzed using Pearson's correlation among nursery characteristics and Pearson's partial correlations between nursery characteristics and growth in height in the field. The correlations were tested using the $t$ test at $5 \%$ level of probability. All these statistical analyses were performed using the SAEG version 9.0 software.
Table 2. Means and standard deviation of parameters evaluated of rooted cuttings evaluated in the nursery immediately before planting in the field.

\begin{tabular}{ccc} 
Parameter & Average & Standard deviation \\
H & 37.2 & \pm 9.92 \\
$\mathrm{D}$ & 3.66 & \pm 0.51 \\
$\mathrm{NLP}$ & 4.38 & \pm 1.37 \\
$\mathrm{NRD}$ & 2.68 & \pm 2.31 \\
$\mathrm{R}-\mathrm{C} / \mathrm{H}$ & 0.54 & \pm 0.13 \\
$\mathrm{CI}$ & 11.70 & \pm 5.07 \\
$\mathrm{R}-\mathrm{H} / \mathrm{D}$ & 10.20 & \pm 2.55 \\
$\mathrm{PC}$ & 4.23 & \pm 0.97 \\
$\mathrm{CL}$ & 3.09 & \pm 0.70 \\
$\mathrm{CA}$ & 4.94 & \pm 0.29 \\
\hline
\end{tabular}

$\mathrm{H}$ : cutting height $(\mathrm{cm})$; D: stem diameter $(\mathrm{mm})$; NLP: number of leaf pairs; NRD: number of root deformation; R-C/H: canopy height and cutting height ratio (number); CI: chlorophyll index (number); R-H/D: cutting height and stem diameter ratio (number); PC: phytosanitary condition (grade); CL: clod length (grade); and CA: clod angle (grade). $(\mathrm{n}=1,176)$

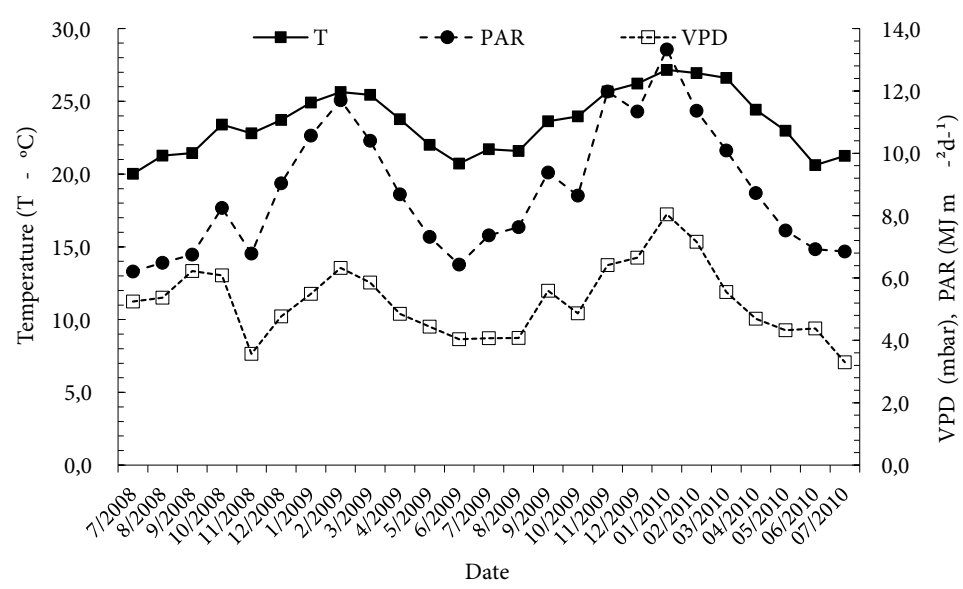

(a)

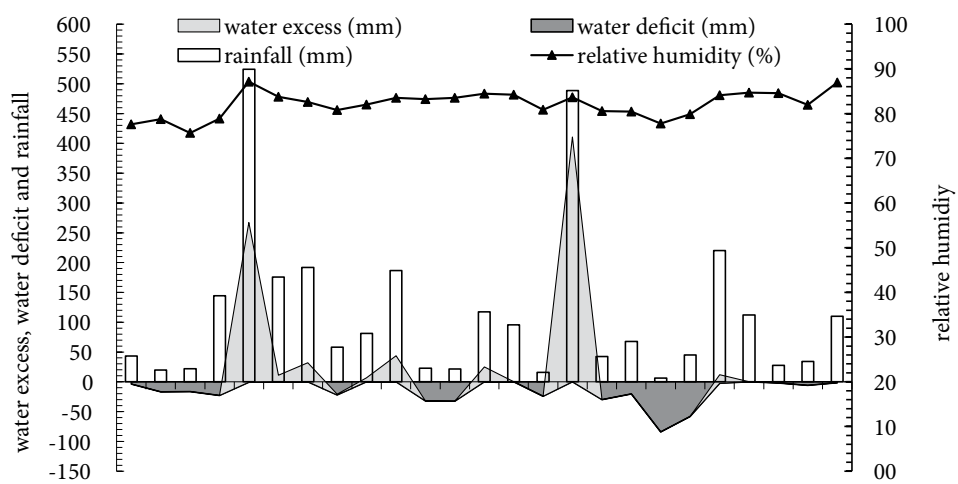

(b)

Figure 2. Climatological data of the experimental area during the 24-month evaluation period after planting (July 2008 to July 2010). T: temperature; VPD ${ }_{\text {air }}$ : vapor pressure deficit in the air; PAR: photosynthetically active radiation. 


\section{RESULTS AND DISCUSSION}

Penchel's (2007) quality control, used in the present study, considers different observation parameters and direct measurements and their ratios. The analysis of correlation between these parameters (Table 3 ) indicated that the following were not significant: $\mathrm{D}$ and $\mathrm{NRD} ; \mathrm{CL}$ and NRD; CA and NRD; and CA and R-C/H; for the other characteristics the correlations were significant. The highest correlation observed was between R-H/D and $\mathrm{H}$, of 0.85 , that as a general rule, according to Cruz \& Regazzi (1994), can indicate that there is a specific problem of collinearity between these parameters of the quality control system proposed by Penchel (2007). This was expected, since R-H/D is a function of $\mathrm{H}$. Usually, in this case, the only one variable should be chosen. Despite this case, the other correlations were below 0.70 (absolute value) and did not indicate a problem of collinearity, by this practical rule.

The R-H/D and D correlation was negative (- 0.08$)$. In this sense, it was clear that it is preferable to use the simple variable of stem height and diameter as indicators of cutting quality, instead of a ratio between these variables. This statement is reinforced by Ataíde et al. (2010) who assessed Eucalyptus cutting density on trays and observed that the restrictions caused by the recipients induced smaller growth in stem diameter. Reis et al. (2008) assessed the spatial variation of Eucalyptus grandis cuttings and their relationship with quality and found various combinations of height and stem diameter among the different treatments, but the relationship of these variables was not statistically different for part of the treatments.

Table 4 shows the height of eucalyptus plants at different periods after planting.

Pearson's partial correlation between the morphological and physiological characteristics of the eucalyptus clonal cuttings, assessed in the nursery, with their growth in height in the field at three and six months after planting, indicated positive correlations for H, NLP, NRD and CL (only at three months), and negative correlation for $\mathrm{D}$ (only at three months) and R-C/H (Table 5).

Cutting height is considered one of the oldest class characteristics for cutting classification and selection. The positive correlation between $\mathrm{H}$ and field height is in agreement with different studies such as that by Barroso et al. (2000), who assessed Eucalyptus camaldulensis and $E$. urophylla up to 10 months after planting, Freitas et al. (2008), who assessed the post-planting performance of eucalyptus clonal cuttings produced in different recipients and substrates up to 180 days after planting, and Figueiredo et al. (2011), who assessed the effect of biometric variations of eucalyptus clonal cuttings on field growth up to 12 months after planting. This correlation was attributed to a selection of the best cuttings in the nursery, with greater heights and consequently greater root development (Freitas et al.,

Table 3. Pearson's correlation matrix between morphological and physiological parameters of eucalyptus clonal cuttings evaluated in the nursery.

\begin{tabular}{|c|c|c|c|c|c|c|c|c|c|c|}
\hline & $\mathbf{H}$ & D & NLP & NRD & R-C/H & CI & R-H/D & PC & CL & CA \\
\hline $\mathrm{H}$ & 1 & - & - & - & - & - & - & - & - & - \\
\hline D & $0.43^{*}$ & 1 & - & - & - & - & - & - & - & - \\
\hline NLP & $0.33^{*}$ & $0.37^{\star}$ & 1 & - & - & - & - & - & - & - \\
\hline NRD & $-0.20^{*}$ & $0.04^{\mathrm{ns}}$ & $-0.06^{*}$ & 1 & - & - & - & - & - & - \\
\hline $\mathrm{R}-\mathrm{C} / \mathrm{H}$ & $0.41^{\star}$ & $0.05^{\star}$ & $-0.05^{\star}$ & $-0.10^{\star}$ & 1 & - & - & - & - & - \\
\hline $\mathrm{CI}$ & $-0.64^{*}$ & $-0.33^{*}$ & $-0.32^{\star}$ & $0.10^{*}$ & $-0.32^{*}$ & 1 & - & - & - & - \\
\hline R-H/D & $0.85^{\star}$ & $-0.08^{\star}$ & $0.14^{\star}$ & $-0.24^{\star}$ & $0.44^{*}$ & $-0.53^{\star}$ & 1 & - & - & - \\
\hline PC & $0.48^{\star}$ & $0.04^{*}$ & $0.20^{*}$ & $-0.32^{\star}$ & $0.17^{\star}$ & $-0.28^{\star}$ & $0.50^{*}$ & 1 & - & - \\
\hline $\mathrm{CL}$ & $0.41^{\star}$ & $0.35^{\star}$ & $0.24^{*}$ & $0.03^{\mathrm{ns}}$ & $0.06^{*}$ & $-0.29^{*}$ & $0.24^{*}$ & $0.19^{*}$ & 1 & - \\
\hline $\mathrm{CA}$ & $0.19^{*}$ & $0.19^{*}$ & $0.05^{*}$ & $-0.0^{\mathrm{ns}}$ & $0.04^{\mathrm{ns}}$ & $-0.12^{*}$ & $0.11^{*}$ & $-0.06^{*}$ & $0.11^{*}$ & 1 \\
\hline
\end{tabular}

H: cutting height; D: stem diameter; NLP: number of leaf pairs; NRD: number of root deformation; R-C/H : canopy height and cutting height ratio; CI: chlorophyll index; R-H/D : cutting height and stem diameter ratio; PC: phytosanitary condition; CL: clod length; and CA: clod angle. ${ }^{*}$ significant at $5 \%$ probability; ${ }^{\text {ns }}$ not significant. 
2005), that provides under favorable field conditions (mainly water in the soil), fast establishment and consequent growth in height.

The number of leaf pairs and clod length correlated positively with plant growth in the field. Inoue \& Ribeiro (1988) studied photosynthesis and transpiration of Eucalyptus grandis and E. saligna clones and concluded that the capacity of the individual to produce and maintain a large leaf area influences different physiological characteristics and can interfere in post-planting performance. The results of these authors converge with those presented in Table 5, showing that outplanting cuttings with a larger leaf number may result in a greater initial growth of the plants.

The correlation observed between clod length and growth in the field shows the importance of the cuttings having a well-developed root system that adheres to the substrate, as emphasized by Carneiro (1995), Gomes \& Paiva (2006) and Alfenas et al. (2009). This result also shows the importance of correctly filling the tubes with substrate and dimensioning and maintaining irrigation sprays, which can contribute to substrate loss.

The partial correlation between the stem diameter and plant height three months after planting presented an inverse negative ratio. This result was also reported by Figueiredo et al. (2011), who worked with eucalyptus clonal plants. The authors observed that cuttings with thin stem diameter (less than $2 \mathrm{~mm}$ ) presented equivalence in growth in height to three months after planting when compared to cuttings with medium (between $2.1 \mathrm{~mm}$ and $3 \mathrm{~mm}$ ) and thick $(3.1 \mathrm{~mm}$ and $4 \mathrm{~mm}$ ) diameter cuttings. On the other hand, because the cuttings were produced in the same recipient, with a rigid wall and small volume $\left(53 \mathrm{~cm}^{3}\right)$, it is believed that a greater root volume may result also in greater occurrence of root deformations so that cuttings with larger diameters would present a greater number of root deformations.

An important point observed regarding root deformations is that they were significant but low magnitude (Table 5). In addition, this correlation increased in the assessment at 12 and 24 months in the field. Thus, the root deformations considered did not damage plant growth until six months after planting, which may be attributed to the low VPD air $_{\text {(Figure 2a) }}$ values and the high rainfall (Figure $2 \mathrm{~b}$ ) that may have

Table 4. Height $(\mathrm{m})$ of eucalyptus plants in different periods after planting.

\begin{tabular}{|ccc|}
\hline $\begin{array}{c}\text { Period after } \\
\text { planting }\end{array}$ & Average & $\begin{array}{c}\text { Standard } \\
\text { deviation }\end{array}$ \\
\hline 3 months & 1.03 & 0.19 \\
\hline 6 months & 2.83 & 0.43 \\
\hline 12 months & 7.49 & 0.91 \\
\hline 24 months & 14.10 & 1.02 \\
\hline
\end{tabular}

Table 5. Pearson partial correlation between morphological and physiological characteristics of eucalyptus clonal cuttings and growth in height, at three, six, 12 and 24 months after planting.

\begin{tabular}{|c|c|c|c|c|}
\hline \multirow{2}{*}{ Parameter } & \multicolumn{4}{|c|}{ Pearson partial correlation } \\
\hline & 3 months & 6 months & 12 months & 24 months \\
\hline $\mathrm{H}$ & $0.00435^{\star}$ & $0.00483^{*}$ & $0.01627^{*}$ & $0.02197^{*}$ \\
\hline $\mathrm{D}$ & $-0.05854^{\star}$ & NS & $-0.46335^{\star}$ & $-0.45612^{\star}$ \\
\hline NLP & $0.02219^{*}$ & $0.04379^{*}$ & $-0.06425^{\star}$ & $-0.05650^{\star}$ \\
\hline NRD & $0.01047^{*}$ & $0.02588^{*}$ & $-0.10132^{*}$ & $-0.08487^{\star}$ \\
\hline $\mathrm{R}-\mathrm{C} / \mathrm{H}$ & $-0.24405^{\star}$ & $-0.46507^{\star}$ & NS & NS \\
\hline $\mathrm{CI}$ & NS & NS & NS & NS \\
\hline R-H/D & NS & NS & NS & NS \\
\hline PC & NS & NS & $0.08868^{\star}$ & $0.10708^{\star}$ \\
\hline $\mathrm{CL}$ & $0.03234^{\star}$ & NS & NS & NS \\
\hline $\mathrm{CA}$ & NS & NS & NS & NS \\
\hline
\end{tabular}

H: cutting height; D: stem diameter; NLP: number of leaf pairs; NRD: number of root deformation; R-C/H: canopy height and cutting height ratio; CI: chlorophyll index; R-H/D: cutting height and stem diameter ratio; PC: phytosanitary condition; CL: clod length; and CA: clod angle. ${ }^{*}$ significant at $5 \%$ probability; NS: not significant. 
provided adequate water assimilation, without adverse consequences for the plants. However, Freitas et al. (2005) assessed eucalyptus growth at two months and emphasized that the persistence of root deformations after planting can reduce or delay plant growth in the field, which, according to Figueiredo et al. (2014), occurs because it interferes in the hydraulic conductivity of the roots and consequently water and nutrient assimilation. In fact, the acquisition of water by the root system and the transport of this molecule throughout the plant establishes a flow (Tyree, 2003), which is originated by the evaporative demand of the tree canopy, constituting a soil-plantatmosphere hydraulic continuum (Nikolova et al., 2009). Therefore, the greater hydraulic conductivity of the root is a crucial factor in the supply of water to the aerial part of the plant. According to Tyree \& Zimmermann (2002), the anatomical characteristics of the root system may have an impact on the hydraulic conductivity of this organ. Huang \& Eissenstat (2000) and Solari et al. (2006) also reported that differences in hydraulic conductivity may be related to root anatomy.

The phytosanitary condition correlated positively with growth in height of the plants at 12 and 24 months after planting, showing the importance of planting healthy cuttings. It is emphasized that the occurrence of diseases in cuttings can result in leaf abscission and consequently reduced photosynthesis rates (Alfenas et al., 2009; Carvalho, 1992; Gomes \& Paiva, 2006).

Indeed, science has shown the importance of cutting quality for successful planting and increase in yield. However, for decision making on a set of characteristics for nursery outplanting, there are few studies that cater specifically to each species, nursery management and edaphoclimatic conditions in the planting sites.

\section{CONCLUSIONS}

The parameters assessed in the nursery that correlated positively with growth in the field at three and six months after planting were height, number of leaf pairs, number of root deformations and clod length. Negative correlations were stem diameter, the canopy length and shoot height ratio.

At 12 and 24 months after planting, the parameters that correlated positively with field growth were height and phytosanitary condition, while the stem diameter, number of leaf pairs and number of root deformations presented inverse correlation.

Although there was significant correlation, the root deformations did not interfere in the initial groups (three and six months) of the plants under high rainfall conditions, but the effects became harmful over time (12 and 24 months), resulting in reduced plant growth.

\section{ACKNOWLEDGEMENTS}

The authors thank the company Fibria Celulose S.A.

\section{SUBMISSION STATUS}

Received: 6 Apr., 2016

Accepted: 26 Apr., 2018

\section{CORRESPONDENCE TO}

\section{Fábio Afonso Mazzei Moura de Assis Figueiredo}

Universidade Estadual do Maranhão (UEMA), Cidade Universitária Paulo VI, Departamento de Zootecnia, Av. Lourenço Vieira da Silva, 1.000, Jardim São Cristovão, CEP 65055-310, São Luís, MA, Brasil

e-mail: figueiredo.uema@gmail.com

\section{REFERENCES}

Alfenas AC, Zauza EAV, Mafia RG, Assis TFV. Clonagem e doenças do eucalipto. Viçosa: UFV; 2009.

Assis TF. Hybrids and mini-cutting: a powerful combination that has revolutionized the Eucalyptus clonal forestry. BMC Proceedings 2011; 5(7): I18. 10.1186/17536561-5-S7-I18

Ataíde GM, Castro RVO, Santana RC, Dias BAS, Correia ACG, Mendes AFN. Efeito da densidade na bandeja sobre o crescimento de mudas de eucalipto. Revista Trópica 2010; 4(2): 21-26.

Barroso DG, Carneiro JGA, Novaes AB, Leles PSS. Efeitos do recipiente sobre o desenvolvimento pós-plantio de Eucalyptus camaldulensis e E. urophylla. Revista Árvore 2000; 24(3): 291-296. 10.5902/19805098414

Carneiro JGA. Produção e controle de qualidade de mudas florestais. Curitiba: UFPR/FUPEF; 1995.

Carvalho CM. Produção de mudas de espécies florestais de rápido crescimento. In: Novaes $\mathrm{AB}$, São José $\mathrm{AR}$, Barbosa AA, Souza IVB, editors. Reflorestamento no Brasil. Vitória da Conquista: UESB; 1992. 
Correia ACG, Santana RC, Oliveira MLR, Titon M, Ataíde GM, Leite FP. Volume de substrato e idade: Influência no desempenho de mudas clonais de eucalipto após replantio. Cerne 2013; 19(2): 185-191. 10.1590/S010477602013000200002

Cruz CD, Regazzi AJ. Modelos biométricos aplicados ao melhoramento genético. Viçosa: UFV; 1994.

Figueiredo FAMMA, Carneiro JGA, Penchel RM, Barroso DG, Daher RF. Efeito das variações biométricas de mudas clonais de eucalipto sobre o crescimento no campo. Revista Árvore 2011; 35(1): 1-11. 10.1590/S010067622011000100001

Figueiredo FAMMA, Carneiro JGA, Penchel RM, Campostrini E, Thiebaut JTL, Barroso DG. Condutividade hidráulica de raiz e capacidade fotossintética de mudas clonais de eucalipto com indução de deformações radiculares. Ciência Florestal 2014; 24: 277-287. 10.5902/1980509814566

Fonseca EP, Valéri SV, Miglioranza E, Fonseca NAN, Couto L. Padrão de qualidade de mudas de Trema micrantha (L.) Blume, produzidas sob diferentes períodos de sombreamento. Revista Árvore 2002; 26(4): 515-523. $10.1590 /$ S0100-67622002000400015

Freitas TAS, Barroso DG, Carneiro JGA, Penchel RM, Coutinho MP. Outplanting performace of eucalyptus clonal cuttings produced in different containers and substrates. Revista Árvore 2008; 32(6): 1019-1028. 10.1590/ S0100-67622008000600007

Freitas TAS, Barroso DG, Carneiro JGA, Penchel RM, Lamônica KR, Ferreira DA. Desempenho radicular de mudas de eucalipto produzidas em diferentes recipientes e substratos. Revista Árvore 2005; 29(6): 853-861. 10.1590/ S0100-67622005000600003

Freitas TAS, Barroso DG, Carneiro JGA, Penchel RM, Souza LS. Efeito de deformações e podas no sistema radicular de mudas clonais de eucalipto sobre o crescimento no campo. Floresta 2009; 39(2): 355-363. 10.5380/rf.v39i2.14562
Gomes JM, Couto L, Leite HG, Xavier A, Garcia SLR. Parâmetros morfológicos na avaliação de qualidade de mudas de Eucalyptus grandis. Revista Árvore 2002; 26(6): 655-664. 10.1590/S0100-67622002000600002

Gomes JM, Paiva HN. Viveiros Florestais: propagação sexuada. 3rd ed. Viçosa: UFV; 2006.

Huang B, Eissenstat DM. Linking hydraulic conductivity to anatomy in plants that vary in specific root length. Journal of the American Society for Horticultural Science 2000; 125(2): 260-264. 10.21273/JASHS.125.2.260

Inoue MT, Ribeiro FA. Fotossíntese e transpiração de clones de Eucalyptus sp e E. saligna. IPEF 1988; (40): 15-20.

Nikolova PS, Blaschke H, Matyssek R, Pretzsch H, Seifert T. Combined application of computer tomography and light microscopy for analysis of conductive xylem area in coarse roots of European beech and Norway spruce. European Journal of Forest Research 2009; 128(2): 145-153. 10.1007/s10342-008-0211-0

Penchel RM. Recomendação técnico-operacional do padrão de qualidade de mudas clonais de eucalipto: instrução normativa da Aracruz Celulose, Documento CPT-P2005-05-2007. Aracruz: Sistema de Gestão OnLine - DOL; 2007.

Reis ER, Lúcio ADC, Fortes FO, Lopes SJ, Silveira BD. Período de permanência de mudas de Eucalyptus grandis em viveiro baseado em parâmetros morfológicos. Revista Árvore 2008; 32(5): 809-814. 10.1590/S010067622008000500004

Solari LI, Pernice F, Dejong TM. The relationship of hydraulic conductance to root system characteristics of peach (Prunus persica) rootstocks. Physiologia Plantarum 2006; 128(2): 324-333. 10.1111/j.1399-3054.2006.00747.x

Tyree MT, Zimmermann MH. Xylem structure and the ascent of sap. Berlin: Springer Verlag; 2002.

Tyree MT. Hydraulic limits on tree performance: transpiration, carbon gain and growth of trees. Trees 2003; 17(2): 95-100. 10.1007/s00468-002-0227-x 